\title{
How do places of origin influence access to mobility in the global age? An analysis of the influence of vulnerability and structural constraints on Senegalese translocal livelihood strategies
}

\author{
Irene Schöfberger \\ formerly at: Institute of Environmental Social Sciences and Geography, Albert-Ludwigs-Universität Freiburg, \\ Freibugr i. Br. 79098, Germany \\ Correspondence to: Irene Schöfberger (irene.schoefberger@gmail.com)
}

Received: 18 June 2016 - Revised: 30 January 2017 - Accepted: 6 March 2017 - Published: 31 March 2017

\begin{abstract}
Literature has often underlined the relevance of mobility for modern lifestyles. However, it has frequently overlooked that mobility has long been the rule in Senegal. There, mobility has allowed households to cope with environmental and economic vulnerability. Over the last decades, households have extended their traditional mobility through internal and international migration. This paper investigates how place-related vulnerability and structural constraints influence the way Senegalese households construct translocal spaces and livelihood strategies in the global age. For this purpose, a multi-sited ethnographic study has been conducted at four villages in Senegal and at two immigration destinations in Italy and Spain. The empirical results show that vulnerability and structural constraints in the home place do not prevent households from adopting strategies based on mobility, but rather influence the composition of translocal spaces, the ability to move between places, and the construction of translocal livelihood strategies.
\end{abstract}

\section{Introduction}

How does vulnerability influence the individual's access to mobility in the global age? The globalisation phenomenon has created complex scenarios of "liquid" and "solid" modernity, where flexible and transboundary flows of persons, goods, and information coexist with fixed structures and nations (Bauman, 2000). The recognition of the increased importance of mobility for modern lifestyles and of the resulting connectivity between social actors has led some authors to focus their attention on movements and on social networks, rather than on places (Crang and Thrift, 2000; Sheller and Urry, 2006). Simultaneously, the awareness of inequalities affecting access to mobility (Cresswell, 2006; Schapendonk and Steel, 2014) has led others to suggest that in the global age "the new mobile global elites" are highly mobile, and "the many workers in the manufacturing and agricultural sectors" remain rooted in place (Featherstone, 2006:390). Other authors and policymakers, finally, have looked at mo- bility as a modern escape strategy from poverty, environmental changes, and further root causes in migrants' home places (Adepoju, 2006; Council of the European Union, 2015). However, in the West African Sahel region, vulnerable households living on agriculture have already been highly mobile for a long time.

Senegalese households, in particular, have for a long time adopted strategies based on mobility, as a way to cope with vulnerability in their home place, and extend their livelihood strategies to diversified extralocal places. This has led to a simultaneous construction of space experiences comprising both mobility and places. In the last decades, Senegalese households have extended these spaces through migration to new destinations worldwide. However, different migrants have different access to immigration destinations, routes, and sources of revenue. Consequently, further differences arise with regard to their possible contribution to collective livelihood strategies. All these inequalities are related to vulnerability and to structural constraints that are experienced both 
at the place of origin and destination (i.e. place related). An analysis of the influence of place-related vulnerability and structural constraints is therefore needed.

This paper aims to investigate how place-related vulnerability and structural constraints influence the way Senegalese households construct translocal spaces and livelihood strategies in the global age. The analysis is conducted through comparison between four Senegalese communities, which are affected by different variables of vulnerability (i.e. agricultural crises, fish scarcity, land scarcity, urbanisation, presence or absence of foreign aid programmes, tourism).

This study draws on a multi-sited ethnographic study conducted at four Senegalese villages, Yoff, Guédé Chantier, Sambé, and Dindéfélo, and at two immigration destinations, Piacenza (Italy) and A Coruña (Spain).

In the first part of this paper, a reconceptualisation of the sustainable livelihood approach in coherence with the case study and with recent criticism is proposed. This reconceptualisation is based on the need to include vulnerability, structural constraints, and translocality in the analysis. In the second part of the paper, space is conceptualised as translocal, in coherence with the case study and with a review of the literature. In the third part of the paper, a comparison between the studied communities is conducted in order to investigate how place-related vulnerability and structural constraints influence the construction of translocality. Finally, some conclusions are drawn.

\section{Methodology and locations of the multi-sited ethnography}

This paper draws on a multi-sited ethnography (see Mendoza and Morén-Alegret, 2013) conducted at four Senegalese villages and in two towns in Italy and Spain. In November 2012-January 2013 and in November 2013-January 2014, two fieldwork phases were conducted at Yoff, Sambé, Guédé Chantier, and Dindéfélo (Senegal). These fieldwork phases included field research in nearby villages and towns. The four villages were selected because they are affected by the following variables of vulnerability: (a) urbanisation and scarcity of land and fishery resources (Yoff); (b) agricultural crises due to intensive land use, partially mitigated by foreign aid (Guédé Chantier); (c) agricultural crises in the absence of foreign aid (Sambé); and (d) an increasing number of tourists and development workers (Dindéfélo). In order to further extend the investigation of translocal spaces, in March and in April 2014, two additional fieldwork phases were conducted at Piacenza (Italy) and at A Coruña (Spain), which according to representatives of the municipality of Yoff are the two main destinations for international migrants from the village. The methodological choice to focus this part of the analysis on Yoff is linked to the considerably higher number of international emigrants there. With respect to the other three villages, Yoff also includes both regular and irregular emi- grants, therefore allowing for a significant sample. It is worth noting that Italy is the second main destination of Senegalese migrants (France being the first and Mauritania the third): in 2013 , it received $13.8 \%$ of all migrants comprised in the population census of that year. Spain, which received $9.5 \%$, is the fourth (ANSD, 2014). Therefore, migration destinations from Yoff can be considered to be within the national tendencies. Further interviews with migrants who had returned for short visits or on a long-term basis were collected at all four Senegalese villages.

Yoff lies in the region of Dakar. This Lebu community, which is the centre of the Layene Brotherhood, enjoys administrative autonomy. It used to be a fishing village, but overfishing due to the presence of foreign fishermen has led to fish scarcity. The number of inhabitants is presently 59675 and the population is rapidly rising ${ }^{1}$. The rapid urbanisation process has led to the impoverishment of a part of the population, while others have benefited from the increased value of land parcels and from arising economic opportunities. International migration is very common at Yoff. Tourism and foreign aid programmes are well represented, as well. The fieldwork for this study was conducted in the seven neighbourhoods constituting the original village.

Guédé Chantier is located in the Senegal River Valley (region of Saint-Louis) and accounts for about 7000 inhabi$\operatorname{tants}^{2}$. It was founded in 1933 by the French colonial administration as an experimental site for intensive rice cultivation. The population is mainly composed of settled and half-nomadic Peul and Tukulor people. Persistent droughts, soil degradation, and farmer indebtedness due to bank credits are increasing emigration tendencies. The village benefits from national and international foreign aid measures.

Sambé lies in the peanut basin (region of Diourbel) and accounts for about 650 inhabitants. Situated in an area with severe desertification tendency, this Serer village has been particularly affected by the agricultural crisis. Unlike farmers at Guédé Chantier, farmers at Sambé do not have access to bank credits and to foreign aid measures. Internal migration is very common in the village.

The fourth village, Dindéfélo, is situated in the region of Kédougou. The local population, which accounts for about 1200 inhabitants and is mostly composed of settled Peul, is progressively abandoning agriculture and engaging in alternative income-generating activities, such as retail and tourist accommodation. Due to the biodiversity of the nearby forest and to the presence of a waterfall, Dindéfélo attracts an increasing number of tourists and development workers. Both

\footnotetext{
${ }^{1}$ Source: http://www.villededakar.org/pages/ commune-darrondissement-de-yoff.

${ }^{2}$ Missing indexes of persons and statistical surveys render it difficult to find exact demographic data for Senegalese villages. Unless stated otherwise, the sources of these and the following population data are interviews with representatives of local municipalities.
} 
internal and international migration are common in the village.

The research methods included participant observation, interviews, informal conversations, and focus groups. The researcher conducted 193 interviews with 195 persons. Some persons were consulted several times, and other persons took part in collective interviews. Forty interviews were conducted at Yoff, 48 at Guédé Chantier, 35 at Sambé, 40 at Dindéfélo, 10 at A Coruña, and 9 at Piacenza. In addition, 11 interviews took place with experts in Dakar. In Senegal, interviewed persons included decision makers, farmers, fishers, herders, migrants, and members of their households. In Italy and Spain, interviewed persons included migrants and representatives of supporting associations. Interviews were conducted in French, Spanish, Italian, English, Wolof, Serer, and Pulaar. Local assistants and interpreters helped with the translation from local languages into French.

Living with local households at the four Senegalese villages and at Piacenza for the whole duration of the fieldwork allowed the researcher to conduct an in-depth participant observation and valuable informal conversations.

The collected material was analysed following an inductive approach (Kuckartz, 2012), in conformity with the grounded-theory methodology (Corbin and Strauss, 2007). This qualitative study focuses on Yoff, Guédé Chantier, Sambé, and Dindéfélo and does not aim to be representative of translocality of all Senegal. Since the vulnerability variables and structural constraints considered in the analysis are present in other Senegalese communities, however, it seems probable that the dynamics explored here may be representative of a wider context.

\section{Livelihood strategies in the translocal space}

Most households of the examined communities are vulnerable. This vulnerability is the result of complex and multidimensional processes and is constituted by (a) exposure to situations of stress and to crises, (b) absence of adequate adaption strategies, and (c) delayed or absent recovery (Bohle and Watts, 1993; Krüger, 2003). Local households are exposed to recurrent situations of stress and to crises that are the result of complex and multilayered environmental, social, and political processes. These include urbanisation (Yoff), increasing land scarcity, and land conflicts (Yoff, Guédé Chantier, Sambé, and Dindéfélo), persistent droughts and soil deterioration (Guédé Chantier and Sambé), increasing bad crops and difficulties in financing agriculture (Guédé Chantier and Sambé), fish scarcity (Yoff), fluctuating tourists flows (Dindéfélo), and irregular foreign aid flows (Yoff, Guédé Chantier, and Dindéfélo).

The sustainable livelihood approach investigates the capabilities, resources, and activities that allow individuals and households in vulnerable contexts to ensure their livelihood while coping and recovering from stress, risks, and shocks, whilst concurrently maintaining or enhancing their means (Chambers and Conway, 1992:6; Scoones, 1998:5). According to this approach, vulnerability contexts are determined by shocks, trends, and seasonality and influenced by transforming structures and processes. Through diverse livelihood strategies, social actors try to maintain or improve their income, well-being, and food security, and to reduce their vulnerability. At the same time, they reconstruct their livelihood assets (i.e. their human, natural, physical, financial, and social capital), which in turn determine their exposure and their access to transforming structures and processes (DFID, 1999).

The sustainable livelihood approach constitutes a good basis for the investigation of the case study. Although mainly oriented towards action, it recognises the relevance of structural constraints and the role of vulnerability and insecurity. Therefore, it suits the analysis of livelihood at the examined villages, where both action and structure play a relevant role. A reconceptualisation of the sustainable livelihood approach according to the present case study - and to recent criticism is needed. In this paper, this reconceptualisation is conducted according to the following three points.

Firstly, the sustainable livelihood approach does not bear enough attention to the relation between livelihood strategies and vulnerability. Indeed, strategies are taken differently in contexts of vulnerability than in contexts of security (Bohle, 2009). At the studied villages, the environmental, social, and political processes mentioned above lead to changing contexts of vulnerability, to which households try to adapt by continuously reconstructing their strategies. These processes of construction are, however, strongly influenced by factors such as the ownership of economic and social capital. In accordance with this first point, this paper analyses the influence of vulnerability on the ability of individuals and households to construct livelihood strategies.

The second criticism refers to structural constraints. The sustainable livelihood approach fails to fully recognise the role of institutions and power structures on the micro and macro level. Access to sources of revenue is structured by social relationships, institutions, and organisations (De Haan and Zoomers, 2005) and therefore marked by property and power relations (Arce, 2003). At the studied communities, intra-household negotiations of livelihood strategies are marked by changing loyalties, diverging perceptions, and conflicting interests. In addition, the adoption of livelihood strategies is limited by wider structural constraints, such as traditional rules, national laws, and international policies. Local households from the four communities are continuously reconstructing their strategies in order to adapt them to changing structural contexts. This paper examines the influence of micro- and macro-level structural constraints on these processes of construction.

Finally, the approach in its original design appears to be inadequate for the analysis of livelihood strategies in translocal spaces (see Steinbrink, 2009; Brickell and Datta, 2011). 
In Senegal and at the examined communities, mobility is a constituent element of livelihood. Households react to vulnerability by extending their livelihood strategies beyond the territory of their village through migration and other practices, such as shifting cultivation and trade. As is analysed in the following section, space is in this way extended translocally and is the hybrid result of different relevant places. The extension of livelihood on translocal spaces and its embedding in places are investigated in this paper.

These three points are interrelated. Therefore, it must be considered that vulnerability itself is translocal. Due to the interrelations between the places composing translocal spaces, actions conducted in one place have an impact on actions conducted in other places and on the ability of households to construct wider livelihood strategies. In this way, different degrees of vulnerability are transmitted and reconstructed in translocal spaces. This can be observed, for instance, with regards to the remittances sent home by migrants. These remittances can strengthen the resilience of households; their measure and effectiveness are, however, influenced by the kind of income-generating activities carried out by the migrants (e.g. street selling or blue-collar employment), which are chosen by migrants according to their vulnerability (including their legal status). In addition, the translocality of structural constraints must be considered. The extension of livelihood strategies beyond the village leads household members living in different places to engage in translocal processes of negotiation. The way macro-level structural constraints are experienced by households is constructed translocally, as well. For instance, vulnerable households whose members lack access to regular migration channels to the European Union due to their inability to fulfil the entry visa requirements may see their situation improved when one of them decides to engage in irregular migration and finally obtains a residence permit allowing him/her to ask for family reunification.

Finally, the analysis of translocal livelihood strategies requires a translocalisation of the concept of household. In accordance with Steinbrink and Peth (2014:33), a translocal household is defined here as a household community that is recognised as such in a specific social context, and whose members coordinate their consumption, reproduction, and resource-use activities on a long term basis. In this concept, cohabitation is no longer considered as a requirement for household membership. In the following section, translocal spaces in Senegal and at the four communities are conceptualised. A brief description of traditional mobility in the region introduces the analysis of contemporary forms of mobility, which are embedded in complex scenarios of "liquid" and "solid" modernity (see Bauman, 2000). In addition, the influence of vulnerability and structural constraints on the abilities of households to move in these scenarios and to construct livelihood strategies in translocal spaces is investigated.

\section{Translocal spaces in the global age}

In Senegal, contemporary migration reproduces in part traditional practices of mobility. It is often stated that the globalisation process has led to increased cross-connectivity between individuals, groups, and states (e.g. Featherstone, 2006) and to a growing deterritorialisation (Backhaus, 2009). A relevant component of this dynamic is mobility, for which increased prominence of modern living has been underlined in the last years (e.g. Sheller and Urry, 2006). Simultaneously, studies on the Sahel region of West Africa have shown that mobility and alternative-space concepts have been present in the area for a long time. Through nomadism and further practices connected to mobility, such as trade and shifting cultivation, the local population has coped with a precarious environmental equilibrium. In this region, mobility can, therefore, be seen as the normal case, rather than as a historical exception (Verne and Doevenspeck, 2012).

Mobility has shaped local space experiences. Historically grounded studies have suggested that in the region space has been organised for a long time as a "fluid and constantly moving territoriality" (Lima, 2013:344. My translation). In other words, space was not based on a fixed delimitation, but rather on social affiliations and structured "like an archipelago" (ibid.). Through processes such as population movements or the creation of new villages, geographically distant places could fall under the control of a single authority (Mbembé, 2005). It was not until the beginning of the colonial administrations that a "rational space" (Walther and Retaillé, 2008:26. My translation), i.e. a space organization based on fixed delimitations, was introduced. A "mobile space" (ibid.), based on social relations as well as on geographical moorings, endures, however, in the lifestyle of local households. This can be observed at the studied villages, as well, where mobility is widely diffused and it includes not only migration, but also practices such as exogamy, participation in ceremonies in other regions, market visits at adjacent villages, access to services at neighbouring towns and pasture farming. Through all these practices, "mobile spaces" are extended beyond the territory of the village and connected with extralocal places and global dynamics.

Mobile spaces are the hybrid and changing result of complex processes of construction. It has been observed that the phenomenon of globalisation is the procedural sum of different processes of change (Fässler, 2007). Whilst it is often conceived in terms of macro-level and homogenising processes, it can rather be observed in "the small, in the concrete, in place, in the own life, and in cultural symbols" (Backhaus, 2009:49. My translation). Through what has been defined as "glocalisation" (Robertson, 1995), interrelations between global processes and local phenomena are established. In this vein, localities "may be imagined as particular articulations of social relations, including local relations 'within' the place and the many connections which stretch way beyond it" (Massey, 1999:22). Places can, therefore, be con- 
ceptualised as the hybrid result of manifold processes of construction. The analysis of space and livelihood strategies in the examined communities requires the adoption of research approaches that can effectively investigate these glocal construction processes.

Investigating mobility and livelihood at Yoff, Guédé Chantier, Sambé, and Dindéfélo requires dedicating attention to both mobility and its embedding into places, and to both local-local and local-global relations. Whereas migration studies have for a long time focused on either origin or destination places, transnational approaches have initiated the shift towards an investigation of the positioning of migrants in both their origin and their destination country and of the social networks stretching between the two nations (e.g. Pries, 2008). This polarisation (Van Bochove, 2012) and the focus on nation states (Brickell and Datta, 2011) have, however, been criticised by the supporters of translocal approaches, who have underlined that most migratory movements occur within national borders and include more than two places. Through the manifold practices of mobility mentioned above, households of the four examined communities extend their livelihood strategies to a plurality of places located both in Senegal and abroad. Additional contacts with supporting social actors allow livelihood strategies to be extended to places where no household member is located. In this paper, a translocal space is conceptualised as being composed by the home village, immigration destinations, places significant for further forms of mobility and places where supporting social actors are located.

Figure 1 illustrates the structure of translocal spaces, based on the results from the interviews with members of the four communities.

In the analysed communities, translocal spaces are the result of construction processes involving the home village and further extralocal places. As illustrated in the next section, actions taking place in each of these locations influence actions in other locations. Paraphrasing Escobar (2001), it can, therefore, be stated that action, like culture, "sits in places". The embedding of spaces into multiple places led some authors to define them as "multi-sited" (e.g. Giraut, 2013). Due to the variety of places and forms of mobility involved, Senegalese multi-sited spaces have been described as spaces of circulation, transformation, and recovery of an alchemy of cultures (Dia, 2014:143). It has, moreover, been written that multi-sited spaces are constructed, read, and interpreted on the individual and collective level "as a kaleidoscope" (Cortes and Pesche, 2013:290. My translation).

Local vulnerability and structural constraints influence the access of individuals to mobility. The globalisation phenomenon does not lead to all-inclusiveness and to a comprehensive political and economic integration. A "liquid modernity", characterised by transboundary flows, still coexists with a "solid modernity", based on national borders (Bauman, 2000). Even if the improvement of infrastructure would allow for an easier circulation of persons, goods, and infor-
Translocal space

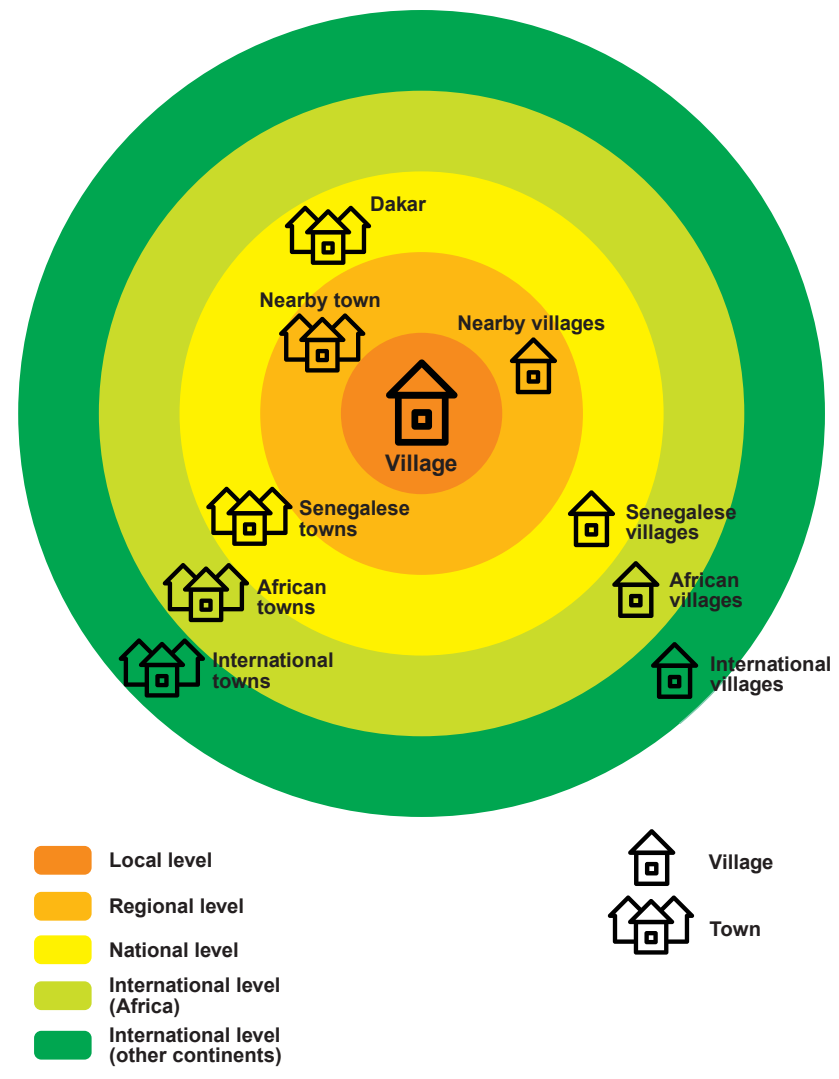

Figure 1. Translocal space.

mation, access to them remains unequal. Being the result of contrasting interests and marked by power structures, mobility policies produce different kinds of (im)mobilities and influence the ability of households to construct translocal spaces.

In the last decades, Senegalese migration patterns have developed according to changing policies and economic opportunities. For instance, when France first restricted the mobility of short-term Senegalese migrants in the eighties, many moved to Italy and Spain, where they could better replicate circular migration patterns (Tall and Tandian, 2011a, b). Simultaneously, in France and soon after in further member states of the Organisation for Economic Cooperation and Development (OECD), short-term migration was widely replaced by the long-term permanence of persons who had "the symbolic capital of education and language" (Bryceson and Vuorela, 2002:7) to fulfil the residence permit requirements. Bilateral migration agreements created further regular migration opportunities for skilled migrants. According to Tall and Tandian, the introduction of barriers to mobility in the 1980s led to a shift from family-based to communityand religion-based migration networks, and in a similar way stricter entry conditions into the European Union are now leading towards increased importance of smuggler networks. 
In this way, a "disjuncture" (Appadurai, 1990) between "liquid" and "solid" modernity has risen: legal migration channels have been established, but they are accompanied by an increased use of irregular migration channels by persons unable to comply with the entry criteria.

The construction of translocality is influenced by vulnerability and structural constraints. Northern migration policies and the costs and risks connected to south-north migration have led to an increased migration selectivity (De Haas, 2009). The ability of individuals to comply with requirements of residence permits - such as education, financial guarantees and contacts in the destination country - is influenced by their degree of vulnerability. For instance, as a result of lower education standards, lack of economic diversification, and major exposure to livelihood crises, individuals from rural households - as opposed to individuals from urban households - experience tougher access to regular migration channels in OECD countries. Migrants from rural regions of Senegal, therefore, tend to stay in Senegal or to move to other African countries, whereas migrants from urban regions tend to choose destinations in the European Union and in North America (ANSD, 2014). Further differences exist between northern immigration destinations. As reported by Tall and Tandian (2011b), highly skilled migrants tend to choose regular migration to the United States and to Canada, and unskilled migrants tend to choose irregular migration to Italy.

Table 1 gives details about immigration destinations in the four communities, as reported by the interviewed persons. Internal migration to Dakar and to other urban and rural areas is practiced by almost all households at Guédé Chantier, Sambé, and Dindéfélo. Due to its low costs and to the scarce legal restrictions regulating it, internal migration is accessible even to highly vulnerable households and can, therefore, provide immediate relief in case of livelihood crises or help finance future investments, such as international migration. International migration can be directed towards other African countries or towards countries in other continents. Thanks to agreements such as the Economic Community of West African States (ECOWAS) Protocol on Free Movement of Persons, Residence, and Establishment, and to their geographical proximity, African countries are legally and financially more accessible to Senegalese migrants than destinations located in other continents. Depending on the country, remittances from Africa may be slightly or sufficiently higher than remittances from internal migration destinations. Migration to African transit countries can, moreover, be adopted as a first step facilitating further migration projects. Interviewees considered migration to OECD member states as possibly the most desirable option, mainly due to the significant remittances that could be sent home. Due to the high costs of both regular and irregular migration channels, some migrants migrate to other African countries as a first step. Finally, migration to other countries (not belonging to the categories above), and in particular to Asian, Arab, and Latin American countries, is gaining relevance. While the costs connected with migration to these countries vary in accordance with their geographical distance, in many cases legal barriers to entry and to the conduction of informal economic activities are (still) low. According to the interviewed persons, remittances from these countries can be estimated as higher than remittances from other African countries and as lower than remittances from OECD member states.

In the following section, the construction of translocal spaces and livelihood strategies is examined. A comparison between the four communities is conducted in order to investigate the role of place-related vulnerability and structural constraints.

\section{Translocality, vulnerability, and structural constraints: a comparison between Yoff, Guédé Chantier, Sambé, and Dindéfélo}

Vulnerability influences the construction of translocal spaces and livelihood strategies, as can be observed through a comparison between the studied communities. At Yoff, migration destinations are more diversified than at the other three villages and in particular at Sambé (see Table 1). Indeed, most migrants from Sambé stay in Senegal or in Africa. Few persons are living in Italy and in Spain, which together with Greece, are the European Union countries which are the easiest to reach via irregular migration routes. A smaller number of other individuals conduct pendulum migration between Senegal and Argentina or Brazil, which are more accessible for Senegalese migrants than most OECD member states. Migrants from Yoff, on the contrary, are living in larger varieties of African countries, OECD member states, and other countries. This different composition of translocal spaces at Yoff and Sambé is related to vulnerability, and influences the adoption of livelihood strategies. At Sambé, households adopt translocal livelihood strategies in order to try to cope with their high degree of vulnerability. However, these strategies are themselves influenced by vulnerability. An enduring agricultural crisis, accompanied by scarce differentiation in the local economy and the absence of relevant foreign aid programmes, has weakened the resilience of the local population. In this context, crises affecting local sources of revenue, such as bad harvest seasons, may have a destructive impact on local livelihood strategies. In order to cope with such risks, and in order to maximise access to alternative sources of revenue, households extend their livelihood strategies to a wider territory through migration. However, poverty, bad education services, and the lack of social contacts limit the access of aspiring migrants from the village to regular migration to the European Union and to further OECD member states. In the following extract from an interview, two relatives of migrants comment on migration options available in the village:

Interviewee 1: He has more than 30 children. They're all gone! 
Table 1. Internal and international destinations of migrants from the four examined villages.

\begin{tabular}{|c|c|c|c|c|c|}
\hline Village & $\begin{array}{l}\text { Internal } \\
\text { migration } \\
\text { destinations } \\
\text { (regions) }\end{array}$ & $\begin{array}{l}\text { African } \\
\text { migration } \\
\text { destinations } \\
\text { (countries) }\end{array}$ & $\begin{array}{l}\text { Migration } \\
\text { destinations } \\
\text { belonging to } \\
\text { the OECD } \\
\text { (countries) }\end{array}$ & $\begin{array}{l}\text { Other migration } \\
\text { destinations } \\
\text { (countries) }\end{array}$ & $\begin{array}{l}\text { Former } \\
\text { migration } \\
\text { destinations } \\
\text { (countries) }\end{array}$ \\
\hline Yoff & $\begin{array}{l}\text { Saint-Louis } \\
\text { Thiès } \\
\text { Ziguinchor } \\
\text { Kaffrine } \\
\text { Matam } \\
\text { Fatick } \\
\text { Diourbel } \\
\text { Louga } \\
\text { Matam } \\
\text { Tambacounda }\end{array}$ & $\begin{array}{l}\text { Ivory Coast } \\
\text { Gambia } \\
\text { Mauritania } \\
\text { Morocco } \\
\text { Cameroon } \\
\text { Equatorial Guinea } \\
\text { Congo } \\
\text { Mali } \\
\text { Gabon } \\
\text { South Africa } \\
\text { Egypt }\end{array}$ & $\begin{array}{l}\text { Spain } \\
\text { Italy } \\
\text { France } \\
\text { Portugal } \\
\text { Greece } \\
\text { Belgium } \\
\text { Netherlands } \\
\text { Germany } \\
\text { Switzerland } \\
\text { UK } \\
\text { Australia } \\
\text { Japan } \\
\text { USA } \\
\text { Canada } \\
\text { Turkey }\end{array}$ & $\begin{array}{l}\text { Argentina } \\
\text { Brazil } \\
\text { Colombia } \\
\text { Ecuador } \\
\text { Peru } \\
\text { United Arab Emirates } \\
\text { Pakistan } \\
\text { India } \\
\text { China }\end{array}$ & $\begin{array}{l}\text { Uruguay } \\
\text { Cape Verde } \\
\text { Gabon } \\
\text { Liberia } \\
\text { Guinea } \\
\text { Conakry } \\
\text { Guinea-Bissau } \\
\text { Gambia } \\
\text { Tunisia }\end{array}$ \\
\hline $\begin{array}{l}\text { Guédé } \\
\text { Chantier }\end{array}$ & $\begin{array}{l}\text { Dakar } \\
\text { Saint-Louis } \\
\text { Louga } \\
\text { Thiès } \\
\text { Ziguinchor }\end{array}$ & $\begin{array}{l}\text { Gabon } \\
\text { Ivory Coast } \\
\text { Mauritania } \\
\text { Congo }\end{array}$ & $\begin{array}{l}\text { Spain } \\
\text { Italy } \\
\text { France } \\
\text { Belgium } \\
\text { USA }\end{array}$ & & \\
\hline Sambé & $\begin{array}{l}\text { Dakar } \\
\text { Diourbel } \\
\text { Touba } \\
\text { Saint-Louis } \\
\text { Louga } \\
\text { Thiès } \\
\text { Kaolack }\end{array}$ & $\begin{array}{l}\text { Gambia } \\
\text { Mauritania } \\
\text { Benin }\end{array}$ & $\begin{array}{l}\text { Spain } \\
\text { Italy }\end{array}$ & $\begin{array}{l}\text { Argentina } \\
\text { Brazil }\end{array}$ & $\begin{array}{l}\text { South Africa } \\
\text { Ivory Coast } \\
\text { Libya }\end{array}$ \\
\hline Dindéfélo & $\begin{array}{l}\text { Dakar } \\
\text { Kédougou } \\
\text { Tambacounda } \\
\text { Touba } \\
\text { Thiès } \\
\text { Mbour }\end{array}$ & $\begin{array}{l}\text { Ivory Coast } \\
\text { Guinea Conakry } \\
\text { Gambia } \\
\text { Mauritania } \\
\text { Mali }\end{array}$ & $\begin{array}{l}\text { Spain } \\
\text { Italy } \\
\text { France } \\
\text { USA } \\
\text { Saudi Arabia }\end{array}$ & & $\begin{array}{l}\text { Burkina Faso } \\
\text { Niger } \\
\text { Algeria } \\
\text { Libya } \\
\text { Czech Republic } \\
\text { Germany }\end{array}$ \\
\hline
\end{tabular}

Interviewee 2: I couldn't ask them to stay. What could they have done here? I wouldn't have been able to feed them. Now, only the youngest is still here. They had no money, but they went... to Dakar and Louga... Not to the United States, because it's difficult for us to get there. To enter the United States, you need at least 3 million [CFA franc]... But where could one ever find them?

Interviewee 1: If somebody has 3 million, he can also stay at home!

[Interviewees 1 and 2 are male relatives of internal migrants, located in Sambé.]
Even if located elsewhere, migrants living in other Senegalese regions and in southern Europe remain "children of their village" (Lima, 2013:345. My translation). Gonin (2010:10. My translation) writes that those who migrate do it "in order to stay or in order to return in better conditions". Like traditional mobility, migration does not constitute a way to escape from the village, but a way to allow other household members to remain there. Through internal migration, remittances can flow through translocal spaces and allow persons who remained at Sambé to continue engaging in agriculture and in other activities that would otherwise be difficult to finance, as illustrated by the following extract from an interview. 
The men of our family collect what they can in Dakar. Then, at the end of the month, they send us money, and we can buy rice, millet, and fish. (...) In the early morning, I go to the market and buy fish and vegetables, which I then retransform in money by selling them to other women of the village (...). This allows me to gain enough to buy what I need.

[Female relative of internal migrants, located in Sambé.]

Different degrees of vulnerability are present at Yoff. There, a rapid urbanisation process, the value increase of land parcels, and conflicts resulting from land sales have led to socioeconomic inequalities between households who have been able to profit from the situation and households who have lost an important component of their livelihood strategies. Some persons can, therefore, comply with the requirements of selective northern migration policies. They are (partially high-) skilled and have access to sufficient economic means to cover the travel expenses, taxes, and financial guarantees connected with regular migration. Whereas at Sambé emigration constitutes a basic strategy to cope with vulnerability, according to local interviewees, at Yoff emigration can be considered an investment. However, the situation is different for emigrants from more vulnerable households, who due to the inability to fulfil northern entry visa requirements, tend to choose African or other south-south destinations. The higher effectiveness of remittances from the European Union, however, lead some of them to engage in irregular migration. To cover the related expenses, aspiring migrants may sell their dugouts or parcels of land, often leading to a strong dependence on remittances of other household members.

Vulnerability is transmitted and reconstructed across translocal spaces. By determining whether persons can have access to regular migration channels, vulnerability in the home place can influence vulnerability in the destination country. Most of the interviewed migrants reported having worse language knowledge, fewer social contacts, and scarcer context-specific information than the majority of their host societies. In addition, due to legal restrictions, irregular migrants have also limited access to housing opportunities and to health, education, and social services. Irregular migrants are also more exposed to structural constraints. For instance, policy conditions such as the link between family reunification and specific definitions of family relations (not including, for example, polygamous marriages) limit the free distribution of household members in the translocal space. Irregular migrants, however, are also excluded both from the possibility to apply for family reunification and from the possibility to move between places (e.g. by conducting home visits). In addition, irregular migrants don't have access to formal employment and have to rely on less profitable informal activities, such as street selling. Compared with regular migrants, they are therefore less empowered to decrease their households' vulnerability.
Social relations with foreign actors can allow Senegalese individuals to gain access to regular migration opportunities that would otherwise be precluded to them, as can be observed at Dindéfélo. The village attracts an increasing number of tourists and hosts a small community of development workers. In the last decades, marriages have been celebrated between foreigners and persons from the village and one person has been adopted by a couple of foreign development workers. Consequently, local households have gained access to immigration destinations such as Spain and the United States. Migrants from the village contribute to shared livelihood strategies both directly through remittances and indirectly through the establishment of partnerships with supporting associations in northern countries. A man explains the deriving advantages as follows:

Tourism has led to an opening of the village. Some boys from Dindéfélo are now married to European women and some girls are married to European men. These relationships have opened a gateway to the rest of the world. This has played an important role. The electricity we now have in our school has been brought by some French partners (...). We have received an ambulance from some young Swiss guys, (...) the solar energy for the women's garden, too (...) so many things! And all this is due to tourism.

[Interviewee is male and located in Dindéfélo.]

Through contacts with supporting external actors, also places where no household member is currently located may be included in translocal spaces. Both Sambé and Guédé Chantier are affected by a severe agricultural crisis. However, whereas at Sambé internal migration is the only possible strategy to gain access to sources of revenue located elsewhere, the community of Guédé Chantier can count on the support of external organisations and associations in Africa, Europe and North America. Some of those contacts have been established by the major of the village, thanks to the encounters and travels involved in his double function of acting president of an Africa-wide development programme and university professor in Dakar. Further contacts have been created by an international migrant in his former country of destination. So far, support measures have included pilot programmes in biological agriculture and fishing, the building of water wells and the provision of school and health material.

Strong foreign aid measures can, however, have a destabilising effect on livelihood strategies. Referring to foreign aid programmes present at Yoff, Guédé Chantier, and Dindéfélo, some of the interviewees commented that they provide externally defined solutions for externally identified problems. Consequently, these programmes don't always correspond to the population's perception of its local needs. According to interviewees, such needs are mainly related to income- 
generating activities (e.g. agriculture and fishing), youth employment, and education. If not based on a shared construction and negotiation of their forms and especially if they imply the distribution of cash, foreign aid measures risk not being harmonised with local strategies and leading to the abandonment of further activities. A woman living in Yoff reported, for instance, that attending a training course organised by a development organisation allowed her to gain knowledge on textile colouring and to start a small business. However, she eventually closed it due to time constraints linked to her participation to further seminars on health and food security organised by the same organisation. Given that the participation was adequately remunerated, continuing her textile-colouring business would have been the most ineffective option. Migrants are in a better position than foreign aid organisations to adapt their support to local livelihood strategies.

Members of translocal households negotiate cultural representations, feelings of belonging and livelihood strategies. The collected interviews show that migrants and their household members at home attribute different emotional and functional meanings to the places composing their shared translocal spaces. Most migrants said that they have developed a sense of belonging to their immigration destinations and to the related social networks. Instead, many of their household members in Senegal said that they hope that migration might allow a transfer of economic wealth, but not be accompanied by a change of local social and cultural constructs. In particular, habits considered as diverging from the local culture and from the Islamic tradition (e.g. individualism or consumption of alcohol) are considered threatening. Some women also reported fearing that their husbands may marry a second wife. Power structures, contrasting interests, and inhomogeneous perceptions among household members furthermore influence negotiations regarding the extent and administration of remittances. Some of the interviewed migrants lamented that their relatives are becoming dependent on them and have partially abandoned alternative sources of revenue, such as agriculture. Implying a lower diversification of the places and sources of revenue on which translocal livelihood strategies are based, this dependence risks weakening the household's long-term resilience. Through intrahousehold negotiations, migrants may, however, try to limit this dependence, as appears in the following extract from an interview.

It has a huge impact on the family. You have fifteen people, and one person works, and (...) that's not good, you know. We need everybody to get an education and get some kind of job, in farming, gardening, in a boutique, as a teacher, whatever. I was in America and I sent money here, but you know, then they don't do anything. (...) We can't just depend on money. What if I die? (...) So I have reorganised my family, now she teaches at school, my brother and my cousin work in the boutique. We do farming. Everyone does something to help the family.

[Former migrant, male, located in Dindéfélo.]

Translocal social networks represent both a support and a hindrance for migrants. In particular, migrants often face considerable economic obligations towards household members in Senegal and commitments related to membership in migrant associations and brotherhoods. Fulfilling such obligations may render it difficult for them to reduce their vulnerability in the host country through investments such as education, better housing, or a car. Social commitments may therefore appear to increase migrants' vulnerability. Simultaneously, however, these commitments reinforce their participation in collective translocal strategies for vulnerability reduction. For instance, members of migrant associations at Piacenza and A Coruña collect resources to be used in the event of sudden deaths and sicknesses, aware that the related expenses would be unbearable for single individuals or households. This allows them to cope with uncertainty. In a similar way, remittances constitute "a regular renewal of the promise of future return" (Sinatti, 2011:160). They sanction the participation of migrants in shared livelihood strategies, despite their temporary physical absence from home. Consequently, Dia and Lacan observe that it is "difficult to establish the balance of an economic situation which is constituted by debits and credits on different social scenes" (2015:71) and by the contextualised and hybrid use of rationalities belonging to different worlds.

The strategies of migrants often follow a hybrid and specifically translocal rationality. Most of the interviewed migrants said that they do not aim at integrating permanently in their host society, but rather at gaining access to extralocal sources of revenue and to supporting social contacts. Consequently, they attribute significant importance to residence permits, which allow them to improve their ability to contribute to translocal livelihood strategies. Residence permits further allow migrants to travel between places and in this way to reinforce social networks (e.g. through home visits) and to adopt specific translocal economic activities (e.g. international businesses and development projects).

\section{Conclusions}

Drawing on a multi-sited ethnographic study conducted at four villages in Senegal and at two immigration destinations in Italy and Spain, this paper has investigated how placerelated vulnerability and structural constraints influence the construction of translocal spaces and livelihood strategies in the global age.

In coherence with the empirical results and with recent criticism, this paper has proposed a reconceptualisation of the sustainable livelihood approach in order to include the translocality of space, vulnerability and structural constraints 
in the analysis. In addition, the constructed and translocal nature of space and the way vulnerability and structural constraints influence its construction in the global age have been examined through an analysis of the case study and a review of the literature. Finally, a comparison of the construction of translocal spaces and livelihood strategies in the communities of Yoff, Guédé Chantier, Sambé, and Dindéfélo has been conducted.

Based on the empirical results, this paper shows that - like traditional mobility - migration is not a way to escape from the village, but a way to allow further household members to remain there. Furthermore, this paper argues that vulnerability and structural constraints in the home place do not prevent households from adopting strategies based on mobility, but rather influence the composition of translocal spaces, the ability to move between places and the construction of translocal livelihood strategies. This paper also argues that translocal spaces and livelihood strategies are the hybrid and changing result of processes of construction and negotiation, in which mobility and its embedding into places are combined. Finally, it argues that, through the subsequent interrelations between places, changing degrees of vulnerability and of exposure to structural constraints are transmitted across translocal spaces.

In the global age, places influence access to mobility. In the "space of flows" (Castells, 1989), Senegalese households' traditional strategies of coping with environmental and economic uncertainty through mobility is increasingly marked by social inequalities. In this context, it is often households who would profit the most from migration that suffer the most relevant restrictions. Consequently, the potential of migration for the resilience of these households and for local development is undermined. In this vein, the call of Tall and Tandian (2011b) for policies allowing to manage migration as an opportunity for development in the global age, rather than as a problem, seems appropriate.

Data availability. In order to guarantee the protection of the personal data and of the privacy of the interviewees, the qualitative data underlying this paper are not publicly available. For further information please contact the author.

Competing interests. The author declares that she has no conflict of interest.

Acknowledgements. The author wishes to thank all interview partners in Senegal, Italy and Spain. She is also grateful to the editor and to three anonymous reviewers for their valuable comments. Finally, she thanks the State Graduate Funding Program of Baden-Württemberg for making this research possible.

Edited by: B. Korf

Reviewed by: three anonymous referees

\section{References}

Adepoju, A.: Reflections on international migration and development in sub-Saharan Africa, African Population Studies, 25, 298-319, 2006.

ANSD (Agence nationale de la statistique et de la démographie): Rapport définitif. Recensement général de la population et de l'habitat, de l'agriculture et de l'élevage 2013, Dakar, Senegal, available at: http://www.ansd.sn/ressources/rapports/ Rapport-definitif-RGPHAE2013.pdf, 2014.

Appadurai, A.: Disjunction and difference in the global cultural economy, in: Global culture: nationalism, globalization and modernity, edited by: Featherstone, M., Sage, London, United Kingdom, 1990.

Arce, A.: Value contestations in development interventions: community development and sustainable livelihood approaches, Community Dev. J., 38, 199-212, 2003.

Backhaus, N.: Globalisierung, Westermann, Braunschweig, Germany, 2009.

Bauman, Z.: Liquid modernity, Polity Press, Cambridge, United Kingdom, 2000.

Bohle, H.-G. and Watts, M.: Hunger famine and the space of vulnerability, GeoJournal, 30, 117-125, 1993.

Bohle, H.-G.: Sustainable livelihood security, evolution and application, in: Facing global environmental change, edited by: Brauch, H. G., Behera, N. C., Kameri-Mbote, P., Grin, J., Oswald Spring, Ú., Chourou, B., Mesjasz, C., and Krummenacher, H., Springer, Berlin, Germany, 2009.

Brickell, K. and Datta, A.: Introduction: Translocal Geographies, in: Translocal Geographies: Spaces, Places, Connections, edited by: Brickell, K. and Datta, A., Ashgate, Farnham, United Kingdom, 2011.

Bryceson, D. and Vuorela, U.: Transnational Families in the Twenty-first Century, in: The Transnational Family: New European Frontiers and Global Networks, edited by: Bryceson, D. and Vuorela, U., Berg Publishers, Oxford, United Kingdom, 3-30, 2002.

Castells, M.: The informational city: information, technology, economic restructuring, and the urban-regional process, Basil Blackwell, Oxford, United Kingdom, 1989.

Chambers, R. and Conway, G.: Sustainable Rural Livelihoods: Practical Concepts for the 21 st century, IDS Discussion paper, 296, https://opendocs.ids.ac.uk/opendocs/bitstream/handle/ 123456789/775/Dp296.pdf?sequence=1, 1992.

Corbin, J. and Strauss, A.: Basics of Qualitative Research: Techniques and Procedures for Developing Grounded Theory, Sage Publications, Thousand Oaks, USA, 2007.

Cortes, G. and Pesche, D.: Territoires multisitués, L'espace géographique, 4, 289-292, 2013.

Council of the European Union: Valletta Action Plan, available at: http://www.consilium.europa.eu/en/meetings/ international-summit/2015/11/action_plan_en_pdf/, 2015.

Crang, M. and Thrift, N.: Introduction, in: Thinking space, edited by: Crang, M. and Thrift, N., Routledge, London, United Kingdom, 1-30, 2000.

Cresswell, T.: On the Move: Mobility in the Modern Western World, Routledge, London, United Kingdom, 2006.

De Haas, H.: Mobility and human development, Human Development Research Paper, 1, UNDP, New York, USA, 2009. 
De Haan, L. and Zoomers, A.: Exploring the frontiers of livelihood research, Dev. Change, 36, 27-47, 2005.

DFID (Department for International Development): Framework, Sustainable livelihoods guidance sheets, London, available at: http://www.eldis.org/vfile/upload/1/document/0901/section2. pdf, 1999.

Dia, H.: Migrations subsahariennes en France : des "villages multisitués", in: Migrations et mutations de la société française, edited by: Poinsot, M. and Weber, S., La Découverte, 139-146, 2014.

Dia, H. and Lacan, L.: Les immigrants sénégalais et l'épargne : une économie domestique multi-située face aux institutions financières françaises, Critique internationale, 4, 59-77, 2015.

Escobar, A.: Culture Sits in Places: Reflections on Globalism and Subaltern Strategies of Localization, in: The Cultural Geography Reader, edited by: Oakes, T. S., Routledge, London and New York, United Kingdom and USA, 287-295, 2001.

Fässler, P. E.: Globalisierung: ein historisches Kompendium, Böhlau, Cologne, Germany, 2007.

Featherstone, M.: Genealogies of the Global, Theor. Cult. Soc., 23, 387-392, 2006

Giraut, F.: Territoire multisitué, complexité territoriale et postmodernité territoriale : des concepts óperatoires pour rendre compte des territorialités contemporaines?, L'espace géographique, 4, 293-305, 2013

Gonin, P.: L'énigme spatiale des Subsahariens, Hommes et migrations, 1286-1287, 6-15, 2010.

Krüger, F.: Handlungsorientierte Entwicklungsforschung: Trends, Perspektiven, Defizite, Petermanns geographische Mitteilungen, 147, 6-15, 2003.

Kuckartz, U.: Qualitative Inhaltsanalyse. Methoden, Praxis, Computerunterstützung, Beltz Juventa, Weinheim, Germany, 2012.

Lima, S.: Territoires multisitués et circulation migratoire, L'espace géographique, 4, 340-353, 2013.

Massey, D.: Imagining Globalization: Power-Geometries of TimeSpace, in: Power-geometries and the Politics of Space-Time, edited by: Hoyler, M., Hettner Lectures, Heidelberg, Germany, 9-23, 1999.

Mbembé, A.: À la lisière du monde. Frontières, territorialité et souveraineté en Afrique, in: Le territoire est mort, Vive les territoires, Antheaume, B. and Giraut, F., IRD Paris, France, 47-77, 2005.

Mendoza, C. and Morén-Alegret, R.: Exploring Methods and Techniques for the Analysis of Senses of Place and Migration, Prog. Hum. Geog., 37, 762-785, 2013.

Pries, L.: Die Transnationalisierung der sozialen Welt. Sozialräume jenseits von Nationalgesellschaften, Springer, Frankfurt a. M., Germany, 2008.
Robertson, R.: Glocalization: time-space and homogeneityheterogeneity, in: Global modernities, edited by: Featherstone, M., Lash, S., and Robertson, R., Sage, London, United Kingdom, 25-44, 1995.

Schapendonk, J. and Steel, G.: Following Migrant Trajectories: the $\mathrm{Im} /$ Mobility of Sub-Saharan Africans en Route to the European Union, Ann. Assoc. Am. Geogr., 104, 262-270, 2014.

Scoones, I.: Sustainable Rural Livelihoods: a framework for Analysis, IDS working paper, 72, https://opendocs.ids.ac.uk/opendocs/ bitstream/handle/123456789/3390/Wp72.pdf?sequence $=1$, 1998.

Sheller, M. and Urry, J.: The New Mobilities Paradigm, Environ. Plann., 38, 207-226, 2006.

Sinatti, G.: 'Mobile transmigrants' or 'unsettled returnees'? Myth of return and permanent resettlement among Senegalese migrants, Popul. Space Place, 17, 153-166, 2011.

Steinbrink, M.: Leben zwischen Stadt und Land. Migration, Translokalität und Verwundbarkeit in Südafrika, VS Verlag für Sozialwissenschaften, Wiesbaden, Germany, 2009.

Steinbrink, M. and Peth, A.: Hier, dort und dazwischen: translokale livelihoods in Südafrika, Geographische Rundschau, 65, 32-38, 2014.

Tall, S. M. and Tandian, A: Migration circulaire des Sénégalais : Des migrations tacites aux recrutements organisés, CARIM notes d'analyse et de synthèse, 52, http://cadmus.eui.eu/bitstream/ handle/1814/18478/CARIM_ASN_2011_52.pdf?sequence=1, 2011a.

Tall, S. M. and Tandian, A: Cadre général de la migration internationale sénégalaise : historicité, actualité et prospective, CARIM notes d'analyse et de synthèse, 54 , http://cadmus.eui.eu/bitstream/handle/1814/18480/CARIM_ ASN_2011_54.pdf?sequence=1, 2011b.

Van Bochove, M.: Truly transnational: the political practices of middle-class migrants, J. Ethn. Migr. Stud., 38, 1551-1568, 2012.

Verne, J. and Doevenspeck, M.: Bitte da bleiben! Sedentarismus als Konstante in der Migrationsforschung in Afrika, in: Migration und Entwicklung aus geographischer Perspektive, edited by: Steinbrink, M. and Geiger, M., IMIS, Osnabrück, Germany, 6194, 2012.

Walther, O. and Retaillé, D.: Le modèle sahélien de la circulation, de la mobilité et de l'incertitude spatiale, Autrepart, 3, 109-124, 2008. 